\title{
Interaction of Precipitation and Groundwater Chemistry - Karnataka, India
}

\author{
G. P. Shivashankara, G. V. Sharmila, and R. Shruthi
}

\begin{abstract}
Precipitation obtained in the form of rain may contribute to surface and sub-surface sources. In this study precipitation and groundwater sampling was done and analyzed for chemical composition in urban, semi-urban and forest areas for the period 2009-2011. The scatter diagram of $D \mathrm{v} / \mathrm{s}{ }^{18} \mathrm{O}$ of groundwater samples were drawn and compared with LMWL. The result indicating that the precipitation plays significant role in the groundwater recharge in the study region. The present study shows that lowest $\mathrm{pH}$ recorded was 6.82 at Bangalore North whereas highest 8.13 at Ramanagar. ANC found to be in Ramanagar $(8.25 \mathrm{meq} / \mathbf{1 0 0 g})$, Bangalore north $(2.71 \mathrm{meq} / \mathbf{1 0 0 g})$, indicating that it has inherent buffering capacity to neutralize the acidity of the precipitation. Soil CEC is in the order Bangalore north<Bangalore south $<$ Mandya $<$ Ramanagar. Decreased CEC resulted by soil acidic processes. Precipitation is the dominant source for the ions present in groundwater and in non-rainy season it is rock dominance.
\end{abstract}

Index Terms-ANC-acid neutralizing capacity, CEC-cation exchange capacity, isotopic composition, $\mathrm{pH}$.

\section{INTRODUCTION}

The chemistry of the precipitation has been studied by numerous investigations during the last three decades due to the increase in environmental problems caused by acid precipitation. The composition of precipitation is important in understanding the role of transport of the soluble components of the atmosphere and the contribution of different sources of atmospheric pollutants.

Precipitation is a form of manifestations of water on earth's atmospheric system. It is the expression of meteorological processes at the ground surface. Its study must first involve a consideration of the processes in the atmosphere which cause the formation of clouds and the further processes which will yield precipitation in the form of water drops or ice particles, and the fate of these as they fall through unsaturated air between the cloud base and the ground surface [1].

Water is a precious and most commonly used resource. It is one of the basic requirements of human beings. Water is available as surface and groundwater. Groundwater is the water which occurs below the surface of the Earth. Most of the Earth's water sources get their water supplies from

Manuscript received May 23, 2015; revised September 18, 2015

G. P Shivashankara is with the Department of Civil Engineering, PES College of Engineering, Visvesvaraya Technological University, Karnataka, India (e-mail: gpshivashankara@yahoo.com).

G. V. Sharmila is with the Environmental Engineering Department of Vidyavardhaka College of Engineering and PES College of Engineering, Mandya, Karnataka, India.

R. Shruthi is with the department of Civil Engineering at BGS Institute of Technology, India. precipitation in the form of rain, snow, hail, dew etc. Precipitation may be defined as the surface water, which evaporates into atmosphere, condenses and returns back to the surface of the Earth in its various forms. Atmospheric precipitation includes its several components like rain, snow,aerosols and dry fallouts, which are powerful diffuse source of environmental pollution since they contain significant quantity of macro and micro elements and represent multi component chemical solutions. The atmospheric precipitation obtained in the form of rain may contribute to the surface and sub surface sources. Generally, precipitation (rain, hail and snow), is alkaline, having $\mathrm{pH}$ more than 5.6. Precipitation is considered acidic, when its $\mathrm{pH}$ is less than 5.6. Normal or neutral $\mathrm{pH}$ of precipitation is 5.6. This value results from the reaction of $\mathrm{CO}_{2}$ with rain in the atmosphere forming carbonic acid and is assumed to be normal or neutral $\mathrm{pH}$ for wet precipitation. Acid rain is caused by the reaction of $\mathrm{SO}_{2}$ and $\mathrm{NO}_{\mathrm{x}}$ with rainwater to form $\mathrm{H}_{2} \mathrm{SO}_{4}$ and/or $\mathrm{HNO}_{3}$, which freely dissociate and yield hydrogen ions and lower $\mathrm{pH}$ values of precipitation. Gases and particles are injected into the atmosphere by natural or anthropogenic sources and are returned to the earth's surface in the form of wet and dry precipitation

Precipitation is the expression of meteorological processes at the ground surface and its study must first involve a consideration of the processes in the atmosphere, which causes the formation of clouds. Spatial distributions of stable isotopes of oxygen and hydrogen in precipitation are powerful tracers for identifying the processes leading to it. It is well established that stable isotopes of oxygen (Oxygen-18) and hydrogen (Deuterium) in water are useful to investigate groundwater recharge, to study the effects of evaporation on groundwater systems, to study groundwater and surface water interaction

Shivashankara (1999) [2] has conducted a study on chemical composition and spatial variation of bulk precipitation in Bangalore city. Based on the analysis, volume weighed annual $\mathrm{pH} 5.20$ which is less than 5.60. The data compared with reported $\mathrm{pH}$ of 6.62 (1974-1984) indicates that bulk precipitation is moving towards acidic precipitation. The data showed that the total depositions of various species over Bangalore city through bulk precipitation were estimated as: $3845 \mathrm{t}$ of $\mathrm{SO}_{4}{ }^{2-}$ which was maximum and accounts for $25 \%$ followed by $3839 \mathrm{t}$ of $\mathrm{HCO}_{3}{ }^{-}(25 \%), 2395 \mathrm{t}$ of $\mathrm{Ca}^{2+}(15 \%)$, $2202 \mathrm{t}$ of $\mathrm{Cl}^{-}(14 \%), 1258 \mathrm{t}$ of $\mathrm{Na}^{+}(8 \%), 579 \mathrm{t}$ of $\mathrm{NO}_{3}{ }^{-}(4 \%)$, $553 \mathrm{t}$ of $\mathrm{K}^{+}(3.6 \%), 422 \mathrm{t}$ of $\mathrm{NH}_{4}{ }^{+}(3 \%), 203 \mathrm{t}$ of $\mathrm{PO}_{4}{ }^{3-}(1 \%)$, $169 \mathrm{t}$ of $\mathrm{Mg}^{2+}(1 \%), 56 \mathrm{t}$ of $\mathrm{NO}_{2}^{-}(0.4 \%)$ and $5.92 \mathrm{t}$ of $\mathrm{H}^{+}$ $(0.05 \%)$. During the period between April 96 and April 98, 
Bangalore city received total deposition of $15526 \mathrm{t}$, out of which alkaline species were 4796t (31\%) and acidic species were 10730 t $(69 \%)$ through bulk precipitation. The city received total deposition excluding $\mathrm{HCO}_{3}$ as $11687 \mathrm{t}$ out of which, alkaline species were $4796 \mathrm{t}(41 \%)$ and acidic species were $6891 \mathrm{t}(59 \%)$ which indicates that the deposition of acidic species are dominated. Munawar Pasha (2005) [3] and Nagendra Prasad B.C. (2006) have conducted a study on bulk precipitation chemistry in urban area. The authors established occurrence of acid rain in North Bangalore and they concluded that sulphate ions are the major ions for the formation of acid rain.

With the review of literatures the objective is to assess the quality of atmospheric precipitation and to determine the chemical composition of precipitation and groundwater composition and to study the $\mathrm{pH}$, Acid Neutralization Capacity and Cation Exchange Capacity of soil and its physicochemical characteristics.

\section{MethodolOGY}

\section{A. Sampling Location}

The geographical locations of the sampling stations are given in the Table I and are shown in Fig. 1. For the study purpose, to collect the bulk (rain+ dust) precipitation samples, the bulk precipitation collectors were placed on the roof of the building. The groundwater samples from bore wells and soil samples were collected at different sampling stations: Hebbal (Bangalore North), Jayanagar (Bangalore South), Ramanagara (Forest area) and Mandya (Semi urban). These stations are located in the vicinity $(<1 \mathrm{Km})$ of the installed precipitation collector [4].

\section{B. Sampling Program and Collection}

In view of assessing the present status of precipitation and groundwater quality, samples were collected. Also to know the vulnerability of soils to anthropogenic activities, grab soil samples were collected in the study area.

\section{1) Collection of bulk precipitation samples}

After each bulk sample was collected, the funnel and reservoir (bottle) was rinsed with distilled water and both were exposed to the next rainfall. All contaminated collectors and tygon pipe were thoroughly rinsed with distilled water. The precipitation samples were collected in pre-washed polyethylene bottles. Sampling programme for collection of bulk precipitation samples was began in 2009 and ended in 2011. Details of sampling stations are shown in Fig. 1. Bulk precipitation samples were collected using bulk precipitation collectors. During the study period (2009-2011), continuous bulk precipitation sampling was carried out manually with the help of enumerators (local observers) all through the seasons from all sampling stations in the study area.

\section{2) Collection of samples to study stable isotope}

Bulk precipitation samples were collected on weekly/biweekly basis from precipitation collector. Every sample included two or more consecutive showers although some samples had one rain event only. Collected samples were visually inspected for contamination by bird breach and algal growth and such samples were discarded. After each bulk sample was collected, the funnel and reservoir (bottle) was rinsed with distilled water and both were exposed to the next rainfall. For the analysis of stable isotopes, this bulk precipitation samples and groundwater samples were collected in HDPE (High Density Poly Ethylene) bottles of 60 $\mathrm{ml}$ capacity. A small air gap was maintained in the bottles for thermal expansion and was labeled. This HDPE bottles were then transported to Isotope Division of Centre for Water Resources Development and Management (CWRDM), Kunnamangalam, Kerala for the analysis of Oxygen and Deuterium.

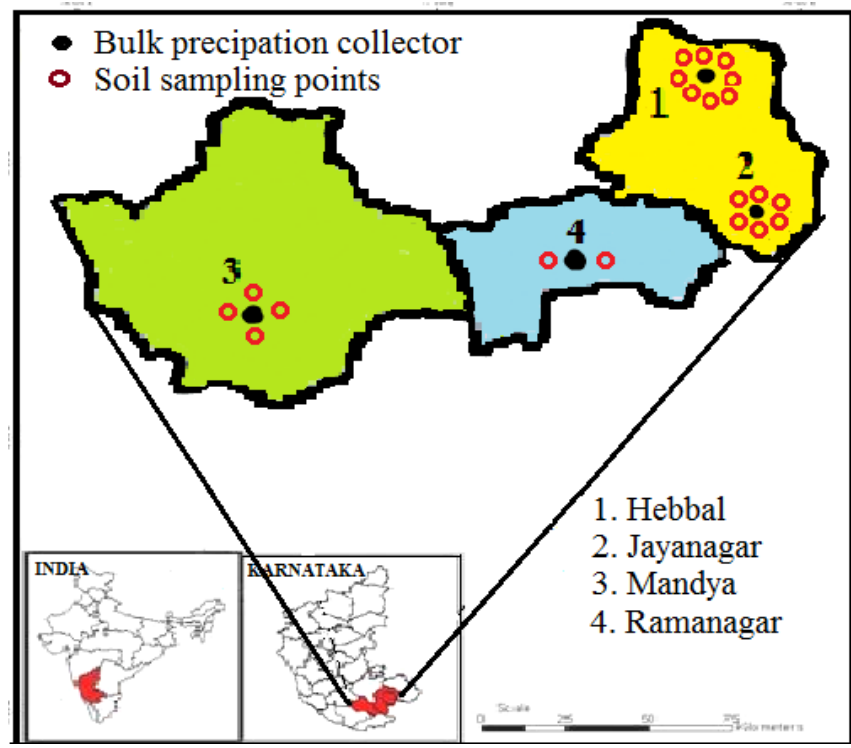

Fig. 1. Study area showing stations for collection of bulk precipitation and soil samples in urban area.

TABLE I: DESCRIPTION OF SAMPLING STATIONS

\begin{tabular}{|c|c|c|c|}
\hline SI. & Site & Latitude/ Longitude & Site Environment \\
\hline 1 & $\begin{array}{l}\text { Hebbal urban } \\
\text { area (Bangalore } \\
\text { North) }\end{array}$ & $13^{\circ} 1^{\prime \prime} \mathrm{N} \quad 77^{\circ} 17.5^{\circ \mathrm{E}}$ & $\begin{array}{c}\text { Mixed (Close to } \\
\text { Highway) }\end{array}$ \\
\hline 2 & $\begin{array}{l}\text { Jayanagar urban } \\
\text { area (Bangalore } \\
\text { South) }\end{array}$ & $12^{\circ} 55^{\prime \prime} \mathrm{N} \quad 77^{\circ} 34^{\prime \prime} \mathrm{E}$ & $\begin{array}{r}\text { Residential \& } \\
\text { Commercial }\end{array}$ \\
\hline 3 & $\begin{array}{l}\text { Mandya semi } \\
\text { urban area }\end{array}$ & $12^{\circ} 33^{\prime \prime} \mathrm{N} \quad 77^{\circ} 36^{\prime \prime} \mathrm{E}$ & Residential area \\
\hline 4 & Ramanagar & $12^{\circ} 55^{\prime \prime} \mathrm{N} \quad 78^{\circ} 02^{\prime \prime} \mathrm{E}$ & Forest area \\
\hline
\end{tabular}

3) Collection of groundwater samples

During study period (2009-2011), groundwater samples were collected on biweekly basis from bore wells located at a vicinity $(<1 \mathrm{Km})$ from the precipitation collector. Groundwater samples were collected in polythene containers of two liter capacity. These containers were carefully cleaned using Hydrochloric acid and thoroughly rinsed in tap water and distilled water before collecting the samples.

Prior to the collection of sample, the bore well water was discharged for two minutes and the containers were rinsed two to three times in the sample water to be collected in order to achieve true representation of the existing condition and securely sealed. Sampling of water was done as per Standard 
Methods [5]. pH, Electrical conductivity and Total Dissolved Solids were measured on site using Calibrated potable $\mathrm{pH}$ meter and Conductivity cell. Then the samples were transported and stored at $4{ }^{\circ} \mathrm{C}$ in refrigerator in Environmental Engineering Laboratory of P.E.S College of Engineering, Mandya until analyzed for various cations \& anions and selected metals.

\section{4) Collection of soil samples}

During study period (2009-2011), grab soil sampling was done in the study area. The soil samples were collected at monthly intervals for rainy and non rainy season.

It was carefully transferred into the polythene bags and analyzed for Moisture content, Permeability, Bulk density Specific gravity and sieve analysis in Geotech laboratory of Civil Engineering Department and pH, heavy metal, like copper, manganese, aluminium, lead were analyzed using Automatic Absorption Spectrophotometer in Environmental

Engineering Laboratory, PES college of Engineering Mandya, as per the Standard Methods [6].

\section{Acid Neutralizing Capacity of Soil}

ANC is defined as the difference between cations of strong bases and anions of strong acids or dynamically as the amount of acid needed to change the $\mathrm{pH}$ value from the sample's value to a chosen different value. ANC is often used in models to calculate acidification levels from acid rain pollution in different geographical areas.

ANC can be determined by various methods. Experimental methods for determining ANC is Gran titration method, EPA method, and Gran analysis etc., P.J.Chapman et al. [7] used the following formula to calculate the ANC.

$$
\mathrm{ANC}=\mathrm{C}_{\mathrm{B}}-\mathrm{C}_{\mathrm{A}} \mathrm{meq} / \mathrm{L}
$$

$$
\mathrm{ANC}=\left(\mathrm{Na}^{+}+\mathrm{K}^{+}+\mathrm{Ca}^{++}+\mathrm{Mg}^{++}\right)-\left(\mathrm{Cl}^{-}+\mathrm{NO}_{3}{ }^{-}+\mathrm{SO}_{4}{ }^{2-}\right) \text { in meq/L }
$$

$\mathrm{C}_{\mathrm{B}}=\left(\mathrm{Na}^{+}+\mathrm{K}^{+}+\mathrm{Ca}^{++}+\mathrm{Mg}^{++}\right)=$sum of strong mineral base cations in meq/ $/ \mathrm{C}_{\mathrm{A}}=\left(\mathrm{Cl}^{-}+\mathrm{NO}_{3}{ }^{+} \mathrm{SO}_{4}^{-}\right)=$sum of strong mineral acid anions in meq/L [7].

\section{Cation Exchange Capacity}

Cation-Exchange Capacity or CEC is defined as the degree to which a soil can absorb and exchange cations $\left(\mathrm{NH}_{4}{ }^{+}, \mathrm{K}^{+}\right.$, $\mathrm{Ca}{ }^{2+}, \mathrm{Fe}^{2+}$, etc...) Soil particles and organic matter have negative charges on their surfaces. Mineral cations can absorb to the negative surface charges or the inorganic and organic soil particles.

Once adsorbed, these minerals are not easily lost when the soil is leached by water and they also provide a nutrient reserve available to plant roots. These minerals can then be replaced or exchanged by other cations (i.e., cation exchange) Cation exchange capacity can be calculated in laboratory by Flame photometer method by using the following formula,

$\mathrm{CEC}=(\mathrm{mg} / \mathrm{L}$ of $\mathrm{Na} \times \mathrm{Vol}$. made up $\times 100 \times A) /(B \times \mathrm{Vol}$. of leachate $\left.\times 0.023 \times 10^{6}\right)$

(meq /100 g)

where:

$A=$ Total volume of the extract $(\mathrm{ml})$,

$B=$ Weight of the air dried soil (g) [8].

\section{RESULT AND DISCUSSION}

\section{A. Precipitation and Ground Water Quality Based on Literature}

\section{1) Precipitation quality}

Munawar Pasha and G. P. Shivashankara conducted a study on urban and rural bulk precipitation chemistry during the period 2005-2007. Based on their study, the volume-weighted mean concentrations of major ions, conductivity and $\mathrm{pH}$ in bulk precipitation samples and precipitation data collected at urban and rural areas during the study period 2009-2011. Table 2 shows the descriptive statistics of bulk precipitation concentrations at urban and rural areas during the study period

\section{2) Ground water quality}

The status of groundwater data of Bangalore urban region during the period of 2003 were collected from the Department of Mines and Geology Government of India Bangalore are represented in pie chart as shown in the Fig. 2.

From the analysis of 918 water samples collected from 735 locations it is found that in 370 locations (48.7\%) the groundwater is not suitable for domestic purposes as stipulated by "Indian Standards - Drinking Water Specifications- Is 10500:1991". In these 370 samples, at least one of the four parameters is above the permissible range. The groundwater from these areas has become non-potable. Only $25.7 \%$ are potable, $23 \%$ use the alternate source, $2.6 \%$ are missing data.

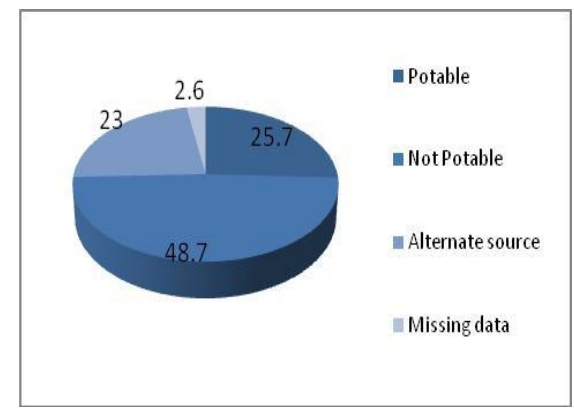

Fig. 2. Status of groundwater quality in Bangalore city, 2003.

\section{B. Bulk Precipitation Quality during Study Period}

Rainfall data were collected on daily basis from all the study areas between 2009 and 2011. These data have been corrected for various heights using standard graph" Shivashankara et al., 1998. For the purpose of this study, it was considered from 2009-10 and 2010-11 as the research commenced in June 2009. Table II summarizes the statistics of bulk precipitation concentrations at sampling stations during study period 2009-2011.

\section{Isotopic Composition of Rainfall}

The available data of the isotopic composition of precipitation were collected from the IAEA/GNIP data base. The Local Meteoric Water Line (LMWL) was constructed and it closely follows the GMWL. However, the intercept value (11.7) of the LMWL was higher than that of the global value of 10 (Craig 1961). The plot showing the LMWL compared with the GMWL is given in Fig. 3.

The scatter diagram of $\delta \mathrm{D} v / \mathrm{s} \delta^{18} \mathrm{O}$ of groundwater 
samples were drawn and compared with LMWL. The groundwater samples plotted very closely to the LMWL indicating that the precipitation plays significant role in the groundwater recharge in the study region. Moreover, the data points are plotted along an evaporative line with a slope of 5.6. This indicates that the rainwater falling in the region is subjected to excessive evaporation at the soil surface prior to its recharge.

This factor is also evident from the enriched average of $\delta^{18} \mathrm{O}$ and low d-excess value of the groundwater samples compared to that of the rainwater. The Scatter plot of $\delta \mathrm{D} v / \mathrm{s}$ $\delta^{18} \mathrm{O}$ of the groundwater samples along with the LMWL is presented in Fig. 4. However, a detailed study including more sampling points and collection of seasonal samples will be required for drawing exact picture of the groundwater recharge mechanism of the location.

TABLE: II: DESCRIPTIVE STATISTICS OF BULK PRECIPITATION Concentration AT SAMPLING STATION DURING StUdy PeRIOd 2009-2011

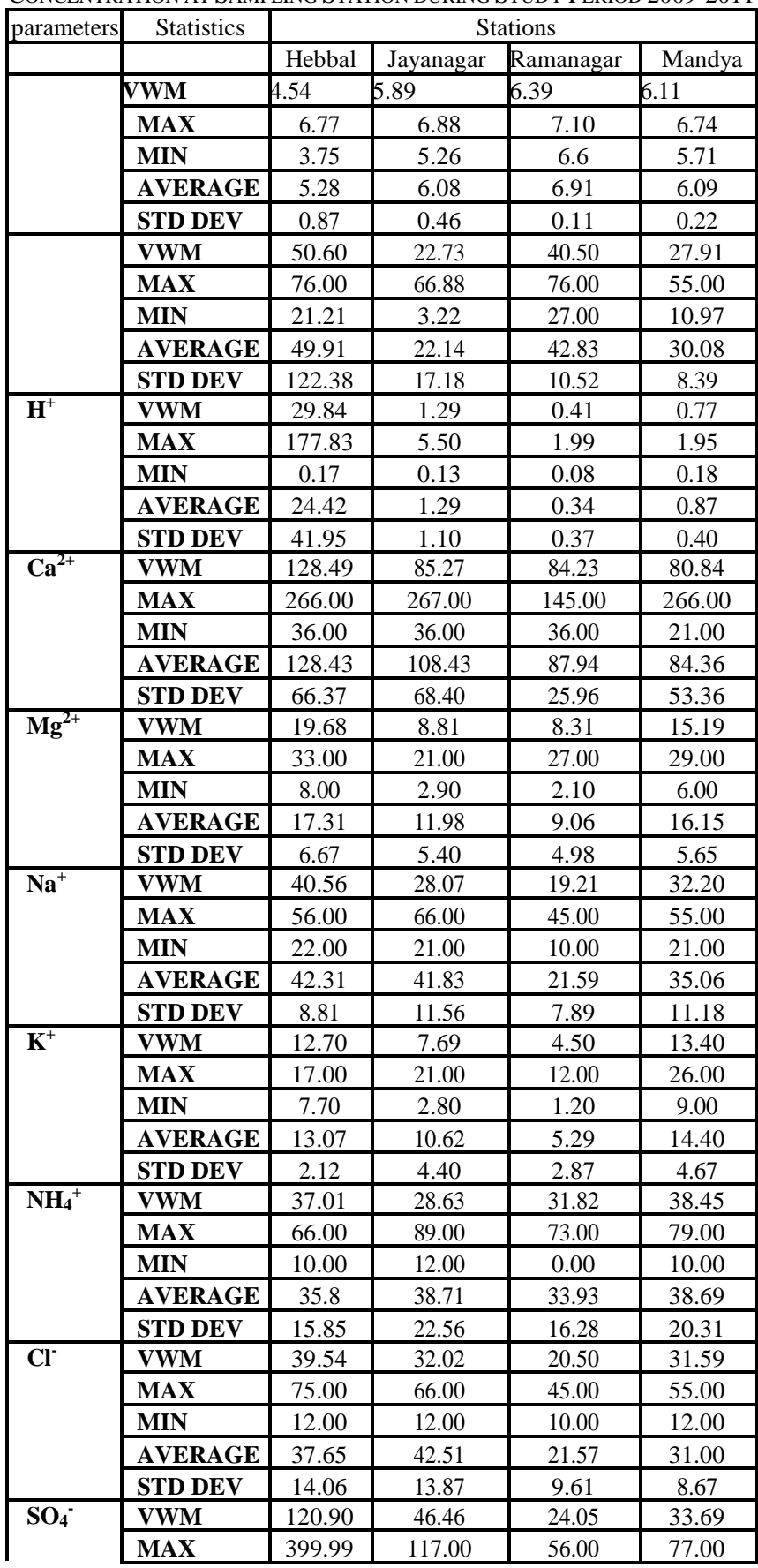

\begin{tabular}{|l|l|c|c|c|c|}
\multicolumn{1}{|c}{} & MIN & 37.00 & 12.00 & 12.00 & 12.00 \\
\cline { 2 - 6 } & AVERAGE & 124.05 & 62.58 & 24.88 & 35.16 \\
\cline { 2 - 6 } & STD DEV & 90.24 & 27.87 & 11.18 & 20.77 \\
\hline HCO $^{-}{ }^{-}$ & VWM & 53.19 & 41.82 & 41.90 & 40.14 \\
\cline { 2 - 6 } & MAX & 112.00 & 86.00 & 89.00 & 66.00 \\
\cline { 2 - 6 } & MIN & 33.00 & 25.00 & 21.00 & 23.00 \\
\cline { 2 - 6 } & AVERAGE & 59.77 & 53.35 & 50.20 & 40.58 \\
\cline { 2 - 6 } & & & & & \\
& STD DEV & 18.57 & 14.11 & 20.15 & 9.89 \\
\hline NO $_{3}{ }^{-}$ & VWM & 46.02 & 39.12 & 32.04 & 37.46 \\
\cline { 2 - 6 } & MAX & 112.00 & 89.00 & 66.00 & 98.00 \\
\cline { 2 - 6 } & MIN & 16.00 & 12.00 & 12.00 & 12.00 \\
\cline { 2 - 6 } & AVERAGE & 49.60 & 53.52 & 35.38 & 40.42 \\
\cline { 2 - 6 } & STD DEV & 25.94 & 26.87 & 12.10 & 18.51 \\
\hline NO $_{2}{ }^{-}$ & VWM & 5.36 & 4.02 & 1.80 & 7.29 \\
\cline { 2 - 6 } & MAX & 12.99 & 10.00 & 17.00 & 21.00 \\
\cline { 2 - 6 } & MIN & 1.60 & 2.00 & 1.00 & 1.60 \\
\cline { 2 - 6 } & AVERAGE & 5.89 & 5.63 & 1.98 & 7.69 \\
\cline { 2 - 6 } & STD DEV & 3.07 & 2.35 & 2.35 & 3.57 \\
\hline PO $_{4}{ }^{3-}$ & VWM & 6.93 & 6.20 & 2.44 & 11.07 \\
\cline { 2 - 6 } & MAX & 15.00 & 17.00 & 7.00 & 23.00 \\
\cline { 2 - 6 } & MIN & 2.50 & 2.00 & 1.00 & 1.17 \\
\cline { 2 - 6 } & AVERAGE & 7.67 & 8.16 & 2.36 & 12.17 \\
\cline { 2 - 6 } & STD DEV & 3.55 & 3.77 & 1.51 & 5.56 \\
\hline & & & & & \\
& & & & \\
\hline
\end{tabular}

TABLE III: Mean Value of Physical Characteristics, ANC, CEC AND HEAVy METAL OF SOIL SAMPLES DURING RAINY SEASON OF THE STUDY PERIOD

\begin{tabular}{|l|l|l|l|l|l|}
\hline Parameters & \multicolumn{4}{|c|}{ Sampling stations } \\
\hline & $\begin{array}{c}\text { Bangalore } \\
\text { north }\end{array}$ & $\begin{array}{c}\text { Bangalore } \\
\text { south }\end{array}$ & $\begin{array}{l}\text { Bangalore } \\
\text { Average }\end{array}$ & Mandya Ramanagar & \\
\hline
\end{tabular}

\begin{tabular}{|l|c|c|c|c|c|}
\hline \multicolumn{5}{|c|}{ Physical characteristics of soil samples } \\
\hline $\mathrm{pH}$ & 6.82 & 7.25 & 7.03 & 7.83 & 8.13 \\
\hline & 164 & 143.8 & 153.9 & 143.1 & 128.43 \\
\hline E.C, $\mu$ S/cm & 4.44 & 5.00 & 4.72 & 5.17 & 5.20 \\
\hline $\begin{array}{l}\text { Moisture } \\
\text { Content, \% }\end{array}$ & 1.757 & 1.821 & 1.789 & 1.918 & 1.98 \\
\hline & 2.48 & 2.52 & 2.50 & 2.70 & 2.83 \\
\hline $\begin{array}{l}\text { Density, g/cm } \\
\text { Bulk density, } \\
\text { g/cm }\end{array}$ & 2.27 & 2.33 & 2.30 & 2.47 & 2.67 \\
\hline Specific gravity & 1.75 & 1.58 & 1.66 & 1.37 & 1.27 \\
\hline $\begin{array}{l}\text { Permeability, } \\
10^{-3} \text { cm/sec }\end{array}$ & 31.37 & 32.23 & 31.8 & 34.63 & 27.88 \\
\hline Liquid limit, \% & 26.22 & 26.54 & 26.38 & 28.07 & 27.15 \\
\hline Plastic limit, \% & & & & & \\
\hline & & & & & \\
\hline
\end{tabular}

\begin{tabular}{|c|c|c|c|c|c|}
\hline \multicolumn{7}{|c|}{ Cations concentration of soil samples } \\
\hline $\mathrm{Ca}^{2+}, \mathrm{meq} / 100 \mathrm{~g}$ & 1.88 & 3.15 & 2.51 & 3.36 & 3.76 \\
\hline $\mathrm{Mg}^{2+}, \mathrm{meq} / 100 \mathrm{~g}$ & 2.29 & 2.49 & 2.39 & 3.78 & 4.31 \\
\hline $\mathrm{Na}^{+}, \mathrm{meq} / 100 \mathrm{~g}$ & 1.25 & 1.00 & 1.12 & 0.67 & 0.41 \\
\hline & 0.46 & 0.51 & 0.48 & 0.58 & 0.66 \\
$\mathrm{~K}^{+}, \mathrm{meq} / 100 \mathrm{~g}$ & Anions concentration of soil samples \\
\hline \multicolumn{7}{|c|}{} \\
\hline
\end{tabular}

\begin{tabular}{|c|c|c|c|c|c|}
\hline & & & & & \\
$\mathrm{Cl}^{-}, \mathrm{meq} / 100 \mathrm{~g}$ & 1.19 & 1.01 & 1.10 & 0.83 & 0.59 \\
\hline $\mathrm{SO}_{4}{ }^{2-}, \mathrm{meq} / 100 \mathrm{~g}$ & 2.16 & 1.21 & 1.68 & 1.11 & 0.81 \\
\hline $\mathrm{NO}_{3}{ }^{-} \mathrm{meq} / 100 \mathrm{~g}$ & 0.46 & 0.29 & 0.37 & 0.21 & 0.11 \\
\hline \multicolumn{7}{|c|}{ CEC and ANC of soil samples } \\
\hline $\mathrm{ANC}$ meq/100g & 2.06 & 4.63 & 3.34 & 5.92 & 7.63 \\
\hline $\mathrm{CEC}$ meq/100g & 8.13 & 10.22 & 9.17 & 10.72 & 11.90 \\
\hline
\end{tabular}

\begin{tabular}{|l|c|c|c|c|c|}
\hline \multicolumn{7}{|c|}{ Heavy metal concentrations of soil samples } \\
\hline $\mathrm{Cu}, \mathrm{mg} / 100 \mathrm{~g}$ & 0.81 & 0.71 & 0.76 & 0.68 & 0.61 \\
\hline $\mathrm{Mn}, \mathrm{mg} / 100 \mathrm{~g}$ & 0.046 & 0.023 & 0.034 & 0.016 & 0.04 \\
\hline $\mathrm{Fe}, \mathrm{mg} / 100 \mathrm{~g}$ & 0.58 & 0.49 & 0.53 & 0.44 & 0.32 \\
\hline $\mathrm{Zn}, \mathrm{mg} / 100 \mathrm{~g}$ & 0.032 & 0.020 & 0.026 & 0.013 & 0.01 \\
\hline
\end{tabular}




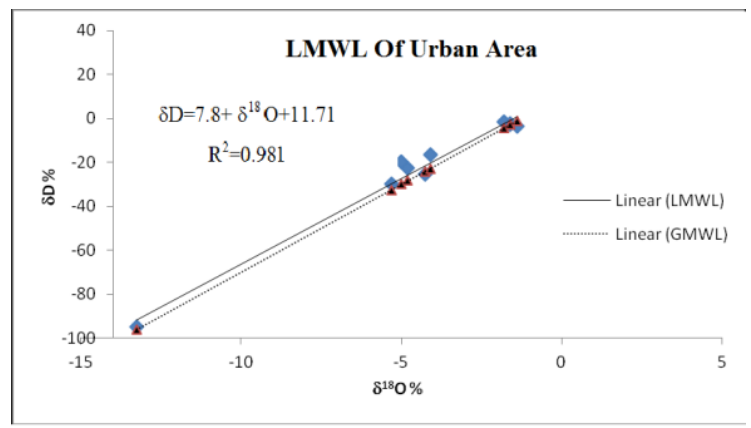

Fig. 3. The local meteoric water line in study area.

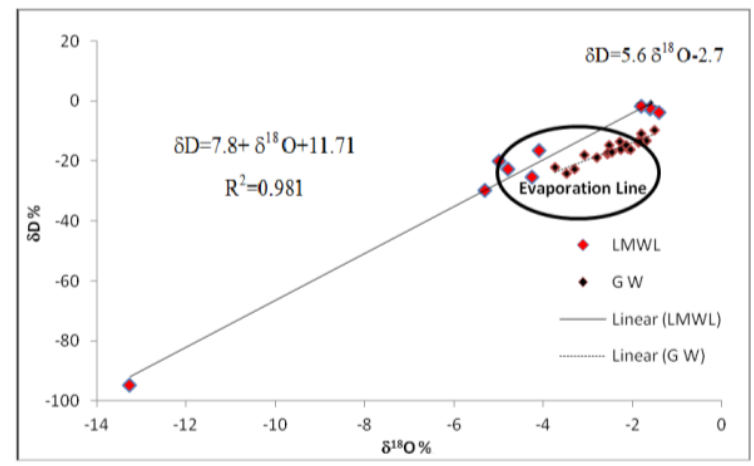

Fig. 4. The scatter plot of $\delta \mathrm{D} v / \mathrm{s} \delta^{18} \mathrm{O}$ of groundwater samples in study area.

\section{Assessment of Acid Neutralizing Capacity}

Review of the Table 3, the concentration of Anions follows the order of $\mathrm{SO}_{4}{ }^{2-}>\mathrm{Cl}^{-}>\mathrm{NO}_{3}{ }^{-}$in all the regions. The Dominant anion $\mathrm{SO}_{4}{ }^{2-}$ and $\mathrm{Cl}^{-}$found to be more in Bangalore North region $(2.16 \mathrm{meq} / 100 \mathrm{~g}$ and $1.19 \mathrm{meq} / 100 \mathrm{~g})$ which could be attributed to the formation of soluble salts of Sulphates, chlorides.

Since nitrogen is highly unstable nitrate concentration is usually less in soil. However, Bangalore North soil samples have high $\mathrm{NO}_{3}{ }^{-}$concentration $(0.46 \mathrm{meq} / 100 \mathrm{~g})$ this can be attributed to high deposition of nitrogen compounds through precipitation [9]. Munawar Pasha and Shivashankara (2007) stated Bangalore north received more acid deposition than alkaline deposition.

The addition of acid to a soil system results in depletion of ANC. As per Table IV, ANC found to be more in Ramanagar region $(8.25 \mathrm{meq} / 100 \mathrm{~g})$, Mandya region $(6.54 \mathrm{meq} / 100 \mathrm{~g})$, compared to Bangalore north $(2.71 \mathrm{meq} / 100 \mathrm{~g})$ and Bangalore south $(5.34 \mathrm{meq} / 100 \mathrm{~g})$, indicating that it has inherent buffering capacity to neutralize the acidity of the precipitation. The higher concentration of anions has reduced the ANC of the Bangalore soil. Though the buffering by the soil minerals tends to increase in soil ANC, further increases in acidity would expect unfavourable changes in soil properties and ANC becomes negative results in soil may fails to neutralize the acidity.

\section{E. Assessment of Soil pH and Cation Exchange Capacity}

Review of the Table III shows that lowest $\mathrm{pH}$ recorded was 6.82 at Bangalore North region and highest $\mathrm{pH}$ recorded was 8.13 at Ramanagar ( $\mathrm{pH}$ of Bangalore South is 7.25 and Mandya 7.83).

The low $\mathrm{pH}$ at Bangalore North could be due to effect of anthropogenic activities in the area which contributes significant effect of anions. The annual $\mathrm{pH}$ of Bangalore urban area is 5.22 for the year 2005-2007 [2]. However, electrical conductivity was observed to be high in Bangalore North region $(164 \mu \mathrm{S} / \mathrm{cm})$ when compared to other stations which indicates that more soluble salts due to anthropogenic activities prevailing in the urban areas. Cation Exchange Capacity (CEC) of all soil samples were analyzed by Sodium acetate method of analysis using Flame photometer.

Table IV, CEC (meq/100g soil) recorded highest in Ramanagar $12.24 \mathrm{meq} / 100 \mathrm{~g}$ (in Bangalore north it is 8.99 $\mathrm{meq} / 100 \mathrm{~g}$ and $10.69 \mathrm{meq} / 100 \mathrm{~g}$ in Bangalore south and Mandya $11.10 \mathrm{meq} / 100 \mathrm{~g}$ respectively) due to dominated in higher concentrations of cations. The CEC of soil samples at all sites has been observed in the order Bangalore north < Bangalore south < Mandya < Ramanagar. The decrease of $\mathrm{CEC}$ and base saturation is resulted by acidic processes. The Mandya region CEC value indicating the characteristics of higher clay content, improved moisture content, where as Bangalore soil result exhibiting the characteristics of low organic matter and low moisture content.

The CEC value is because of the more exchangeable sites available in these soils compared to urban soils which mean that soil have higher capacity to hold more number of cations and requires more capacity to replace the cations adhered to clay particles [10]. The study established that forest area and semi-urban soils have more buffering capacity to neutralize soil $\mathrm{pH}$.

\section{F. Groundwater Quality during Study Period}

The mechanisms that significantly control the chemical composition of the dissolved salts of the water of the earth in major proportion have been discussed by Gibbs. Among all the investigators Gibbs in describing the mechanism of controlling the chemistry of different type of waters happen to be most appropriate. He proposed a diagram in which the domain of each of the three major controlling mechanism and factors i.e. atmospheric precipitation, Rock dominance and evaporation-crystallization has clearly been demarcated To know the groundwater chemistry and relationship of the chemical components of water from their respective aquifers such as chemistry of the rock types, chemistry of precipitated water and rate of evaporation, Gibbs (1970) [11] has suggested a diagram in which ratio of dominant anions and cations are plotted against the value of total dissolved solids (TDS).Gibbs diagrams, representing the ratio-I for cations $[(\mathrm{Na}+\mathrm{K}) /(\mathrm{Na}+\mathrm{K}+\mathrm{Ca})]$ and ratio-II for anions $\left[\mathrm{Cl} /\left(\mathrm{Cl}+\mathrm{HCO}_{3}\right)\right]$ as a function of TDS are widely employed to assess the functional sources of dissolved chemical constituents.

Fig. 5 - Fig. 12 shows the Gibbs diagram for rainy and non-rainy season for the four stations of study area. In all the stations, about $80-90 \%$ of sampling stations are recharged by the precipitation. It is the dominant source for the ions present in the groundwater and in non-rainy season it is the rock dominance. The data of physico-chemical parameters of groundwater of Hebbal region during study period showed that the water is not fit for drinking. Since nitrate, TDS and heavy metal concentrations exceeded the permissible limit in Hebbal region. The heavy metal parameters shows that $\mathrm{Al}^{3+}$ ion concentration in the groundwater of Hebbal and Jayanagar 
region exceeds the maximum permissible limit $0.2 \mathrm{mg} / \mathrm{L}$. As expected, the high $\mathrm{Al}^{3+}$ ion concentrations are associated with groundwater which is recharged with water of lower $\mathrm{pH}$ values(<6.5). $\mathrm{Al}^{3+}$ mobilization from insoluble forms in minerals and rocks is governed mainly by the $\mathrm{pH}$ of the solution surrounding weathering minerals [12]. The maximum permissible limit for lead level for water potability is $0.01 \mathrm{mg} / \mathrm{L}$. In the study area, it is slightly higher than the permissible limit. The copper concentration is below detection but it has not exceeded the permissible limit of 2 $\mathrm{mg} / \mathrm{L}$.

TABLE IV: Mean Value of Physical Characteristics, ANC, CEC and Heavy Metal of Soil Samples During Non Rainy Season of the Study PERIOD

\begin{tabular}{|c|c|c|c|c|c|}
\hline \multirow[t]{2}{*}{ Parameters } & \multicolumn{5}{|c|}{ Sampling stations } \\
\hline & Bangalore north & Bangalore south & Bangalore Average & Mandya & Ramanagar \\
\hline \multicolumn{6}{|c|}{ Physical characteristics of soil samples } \\
\hline $\begin{array}{l}\text { E.C, } \mu \mathrm{S} / \mathrm{cm} \\
\text { Moisture } \\
\text { Content, } \% \\
\text { Density, } \mathrm{g} / \mathrm{cm}^{3} \\
\text { Bulk density, } \\
\mathrm{g} / \mathrm{cm}^{3} \\
\text { Specific gravity } \\
\text { Permeability, } \\
10^{-3} \mathrm{~cm} / \mathrm{sec}\end{array}$ & $\begin{array}{c}7.06 \\
166.5 \\
\\
5.77 \\
1.744 \\
3.39 \\
\\
2.54 \\
1.92\end{array}$ & $\begin{array}{c}7.68 \\
151.4 \\
\\
6.26 \\
1.789 \\
2.69 \\
\\
2.70 \\
1.74\end{array}$ & $\begin{array}{c}7.37 \\
158.9 \\
\\
6.01 \\
1.766 \\
3.04 \\
\\
2.62 \\
1.83\end{array}$ & $\begin{array}{c}8.04 \\
147.3 \\
\\
6.63 \\
1.880 \\
2.80 \\
\\
2.81 \\
1.44\end{array}$ & $\begin{array}{c}8.52 \\
135.60 \\
\\
6.79 \\
1.99 \\
2.94 \\
\\
2.91 \\
1.45\end{array}$ \\
\hline Liquid limit, \% & 28.62 & 30.47 & 29.54 & 33.41 & 27.63 \\
\hline Plastic limit, \% & 24.13 & 25.09 & 24.61 & 27.27 & 26.28 \\
\hline \multicolumn{6}{|c|}{ Cations concentration of soil samples } \\
\hline $\begin{array}{ll}\mathrm{Ca}^{2+}, \text { meq } / 100 \mathrm{~g} & \\
\mathrm{Mg}^{2+}, & \\
\mathrm{meq}^{+} / 100 \mathrm{~g} & \\
\mathrm{Na}^{+}, \text {meq } / 100 \mathrm{~g} & \\
\mathrm{~K}^{+}, \text {meq } / 100 \mathrm{~g} \\
\end{array}$ & $\begin{array}{l}2.42 \\
2.63 \\
\\
1.46 \\
0.54 \\
\end{array}$ & $\begin{array}{l}3.66 \\
2.95 \\
\\
1.14 \\
0.63 \\
\end{array}$ & $\begin{array}{l}3.04 \\
2.79 \\
\\
1.30 \\
0.58 \\
\end{array}$ & $\begin{array}{l}3.85 \\
3.56 \\
\\
0.99 \\
0.69 \\
\end{array}$ & $\begin{array}{l}4.18 \\
4.50 \\
\\
0.59 \\
0.85 \\
\end{array}$ \\
\hline \multicolumn{6}{|c|}{ Anions concentration $\quad$ of soil samples } \\
\hline $\begin{array}{l}\mathrm{Cl}^{-}, \text {meq } / 100 \mathrm{~g} \\
\mathrm{SO}_{4}{ }^{2-} \text { meq } / 100 \mathrm{~g} \\
\mathrm{NO}_{3}{ }^{-} \text {meq } / 100 \mathrm{~g} \\
\end{array}$ & $\begin{array}{l}1.39 \\
2.38 \\
0.50 \\
\end{array}$ & $\begin{array}{l}1.24 \\
1.37 \\
0.37 \\
\end{array}$ & $\begin{array}{l}1.31 \\
1.87 \\
0.43 \\
\end{array}$ & $\begin{array}{l}0.95 \\
1.26 \\
0.27 \\
\end{array}$ & $\begin{array}{l}0.70 \\
0.96 \\
0.21 \\
\end{array}$ \\
\hline \multicolumn{6}{|l|}{ CEC and ANC of soil samples } \\
\hline $\begin{array}{l}\text { ANC meq/100g } \\
\text { CEC meq/100g }\end{array}$ & $\begin{array}{l}2.71 \\
8.99 \\
\end{array}$ & $\begin{array}{c}5.34 \\
10.69 \\
\end{array}$ & $\begin{array}{l}4.02 \\
9.84 \\
\end{array}$ & $\begin{array}{c}6.54 \\
11.10 \\
\end{array}$ & $\begin{array}{c}8.25 \\
12.24 \\
\end{array}$ \\
\hline \multicolumn{6}{|c|}{ Heavy metal concentrations of soil samples } \\
\hline $\begin{array}{lr}\mathrm{Cu}, & \mathrm{mg} / 100 \mathrm{~g} \\
\mathrm{Mn}, \mathrm{mg} / 100 \mathrm{~g} & \\
\mathrm{Fe}, \quad \mathrm{mg} / 100 \mathrm{~g} \\
\mathrm{Zn}, \quad & \mathrm{mg} / 100 \mathrm{~g}\end{array}$ & $\begin{array}{c}1.00 \\
0.061 \\
0.81 \\
\\
0.049\end{array}$ & $\begin{array}{c}0.84 \\
0.044 \\
0.63 \\
0.033\end{array}$ & $\begin{array}{c}0.92 \\
0.052 \\
0.72 \\
\\
0.041\end{array}$ & $\begin{array}{c}0.79 \\
0.030 \\
0.58 \\
\\
0.023\end{array}$ & $\begin{array}{l}0.62 \\
0.45 \\
0.02 \\
\\
0.02\end{array}$ \\
\hline
\end{tabular}

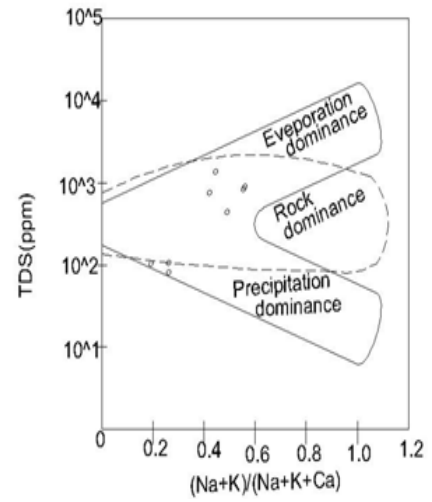

(a)

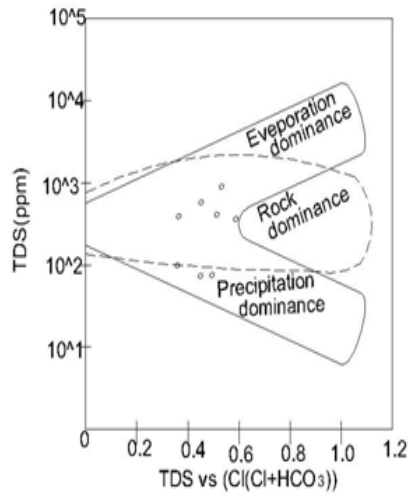

(b)

Fig. 5. Cation (a) and anion (b) mechanism controlling the ground water chemistry during the rainy season in Hebbal.

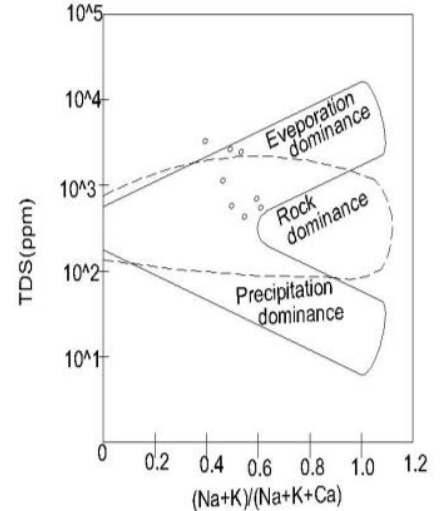

(a)

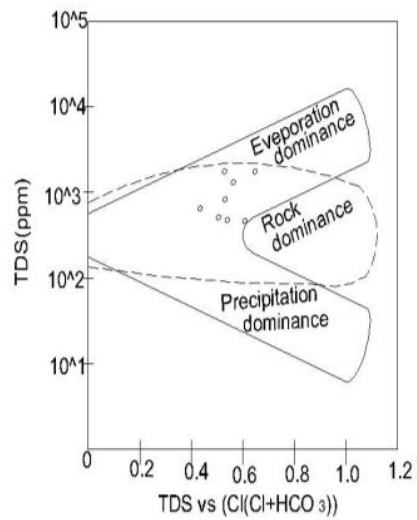

(b)

Fig. 6. Cation (a) and anion (b) mechanism controlling the ground water chemistry during the non-rainy season in Hebbal. 


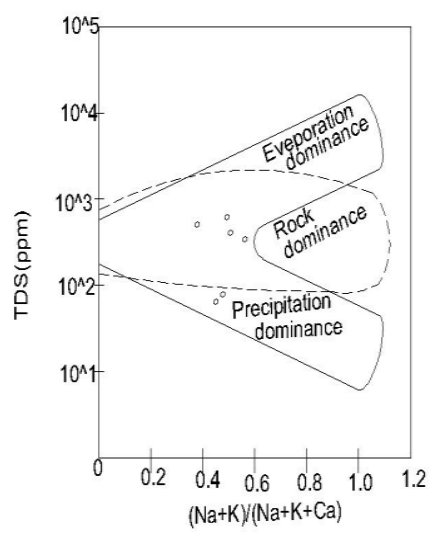

(a)

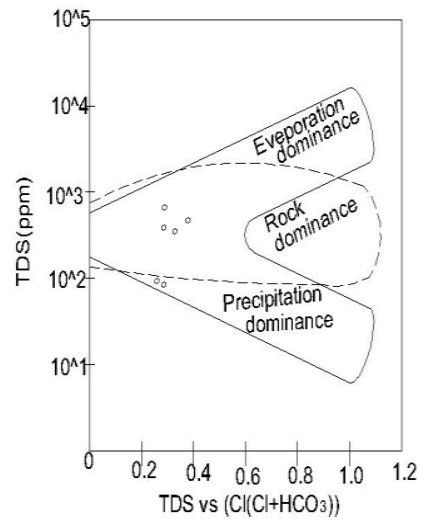

(b)

Fig. 7. Cation (a) and anion (b) mechanism controlling the controlling the ground water chemistry during the rainy season in Jayanagar.

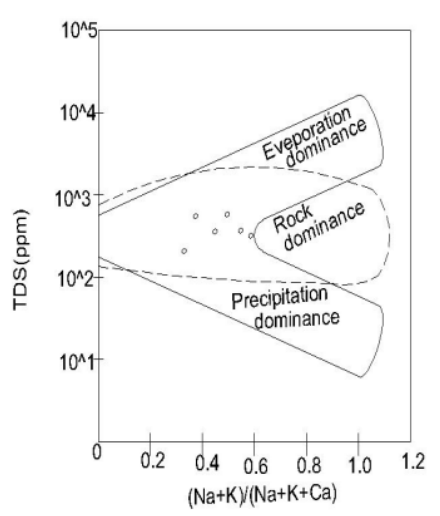

(a)

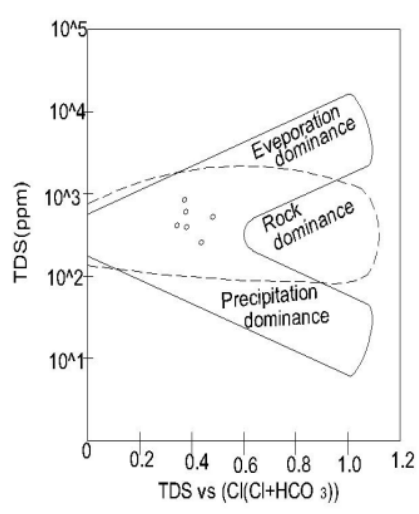

(b)
Fig. 8. Cation (a) and anion (b) mechanism controlling the ground water chemistry during the non-rainy season in Jayanagar.

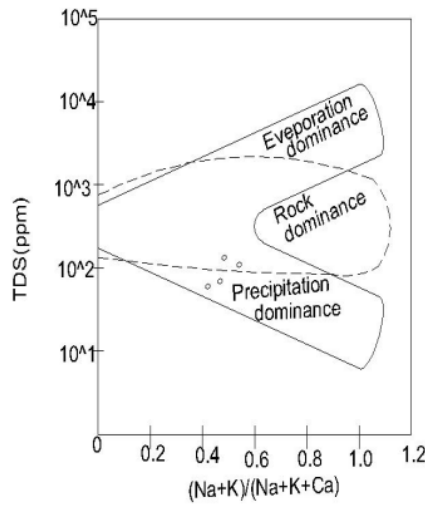

(a)

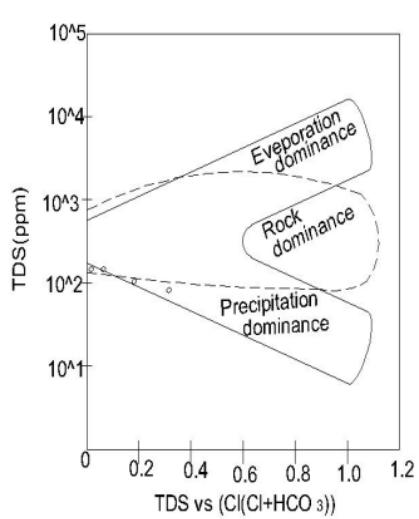

(b)
Fig. 9. Cation (a) and anion (b) mechanism controlling the ground water chemistry during the rainy season in Mandya.

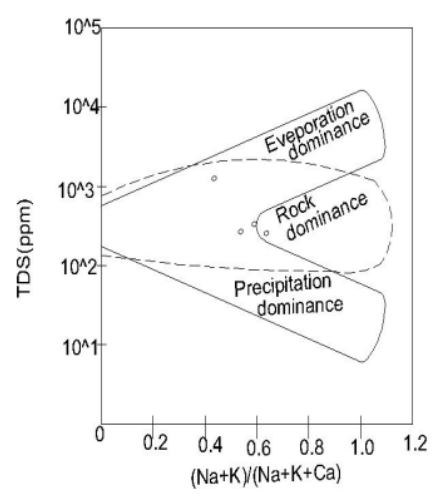

(a)

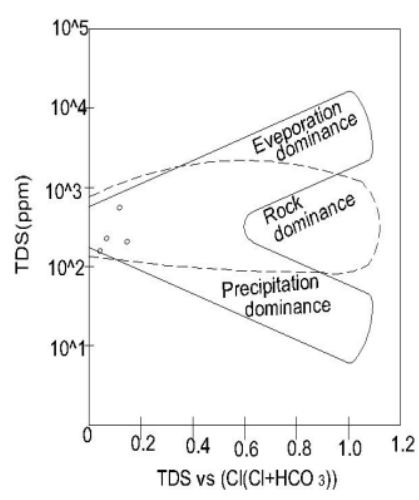

(b)
Fig. 10. Cation (a) and anion (b) controlling the ground water chemistry during the non rainy season in Mandya.

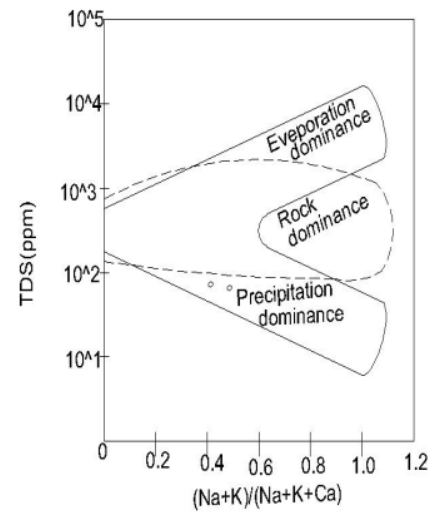

(a)

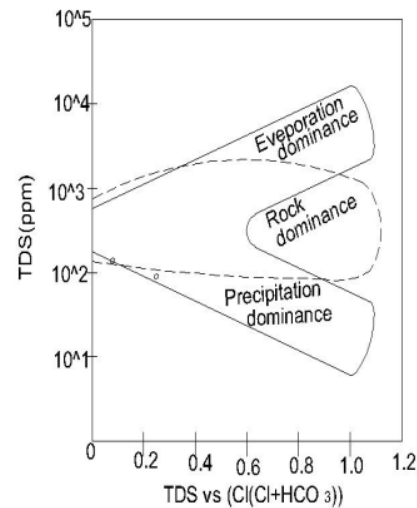

(b)
Fig. 11. Cation (a) and anion (b) mechanism controlling the ground water chemistry during the rainy season in Ramanagar.

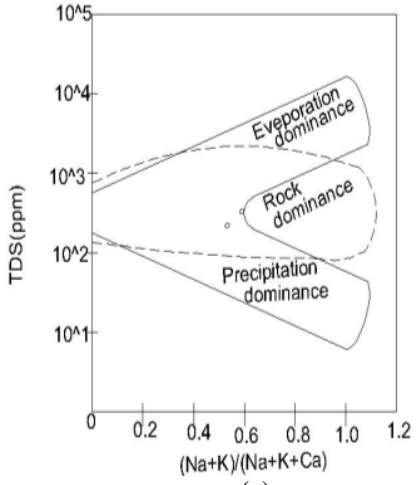

(a)

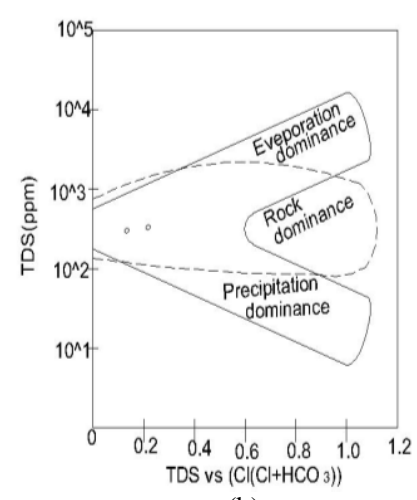

(b)
Fig. 12. Cation (a) and anion (b) mechanism controlling the ground water chemistry during the rainy season in Ramanagar.

\section{CONCLUSION}

1) The scatter diagram of $\delta \mathrm{D} v / \mathrm{s} \delta^{18} \mathrm{O}$ of groundwater samples were drawn and compared with Local Meteoric Water Line (LMWL). The groundwater samples plotted very closely to the LMWL indicating that the precipitation plays significant role in the groundwater recharge in the urban, semi-urban and forest area.

2) Gibb's plot reveals that the groundwater samples in both seasons in Hebbal and Jayanagar regions have an interaction between the lithological units and the percolating water into the subsurface as depicted by majority samples in the rock dominance field. Hence, concluded that the overall quality of groundwater is controlled by lithology apart from other local environmental conditions and anthropogenic activities.

3) $\mathrm{pH}$ of the soil was found to be increased during rainy when compared to non-rainy in all urban, semi-urban and forest areas.

4) Due to the availability of more exchangeable cations in Mandya region compared to urban region indicates that it has greater capacity to hold cations resulting in higher neutralizing capacity and the CEC of Hebbal region is less due to low concentration of cations.

5) Acid neutralizing capacity of the Ramanagar forest area soil is highest followed by Mandya, Jayanagar and Hebbal of Bangalore region. SinceHebbal region receiving acid deposition this could be the reason for higher acidic anions concentration in Hebbal results in lower acid neutralizing capacity. 
6) Increasing in CEC has been obsevered in urban and semi-urban regions from rainy to non-rainy season. This concludes the soil has not lost their acid neutralizing capacity and soils are still alkaline in nature.

7) Variation has been observed in heavy metal concentration from rainy to non-rainy season. The concentration of heavy metals is comparatively high in Hebbal region from than Jayanagar, Mandya and Ramanagar regions. This is due to some industrial activities and automobile emission. It will impact on soil quality.

8) The concentration of cations and anions in the groundwater is more in Hebbal region because the Acid Neutralizing Capacity of the soil is less $(2.06 \mathrm{meq} / 100 \mathrm{~g}$ and $2.71 \mathrm{meq} / 100 \mathrm{~g}$ ) during study period when compared to Jayanagar and Mandya regions and also the rate of permeability is more in Hebbal region 1.75 and $1.92 \mathrm{x}$ $10^{-3} \mathrm{~cm} / \mathrm{sec}$

\section{REFERENCES}

[1] R. G. Dzhamalov and V. L. Zlobina, "Precipitation pollution effect on groundwater hydrochemical regime," Environmental Geology, vol. 25, pp. 65-68, 1994.

[2] G. P. Shivashankara, K. Ranga, and M. Rao, "Chemical composition and spatial variation of bulk precipitation in Bangalore city," $\mathrm{PhD}$ thesis, University of Bangalore, Karnataka, India, 1998.

[3] M. Pasha and G. P. Shivashankara, "Urban and rural bulk precipitation chemistry," Ph.D thesis, VTU, Belgaum, Karnataka, 2010

[4] S. B. Olobaniyi and S. I. Efe, "Comparative assessment of rainwater and groundwater quality in an oil producing area of Nigeria," Water Resources Journal of the Nigerian, 2007.

[5] APHA: Standard Methods for the Examination of Water and Wastewater, 21 ${ }^{\text {st }}$ Edition, Washington, D.C., 2005.

[6] N. Srinivasa, S. S. Prakas, and Krishnamurthy, "Manual for soil chemistry," Department of Soil Science and Agriculture Chemistry, Agriculture College.

[7] P. J. Chapman, B. Reynolds, and H. S. Wheater, "The seasonal variation in soil water and acid neutralizing capacity in Peaty Podzols in Mid Wales," Water, Air and Soil Pollution, vol. 85, pp. 1089-1094, 1995.

[8] C. A. Srinivasmurthy and R. Parama, "Practical manual for hands on training/ experiential learning," Department of Agriculture Chemistry, College of Agriculture.

[9] L. Blake and. K. W. T. Goulding, "Effect of atmospheric deposition, soil $\mathrm{pH}$ and acidification on heavy metal content in soil R," 2002.

[10] N. R. Pattabhiramaiah, "District wise Geology and Mineral Resources of Karnataka," Department of Mines And Geology, Bangalore, 2001.

[11] J. Gibbs, "Mechanism controlling world water chemistry," Science, vol. 170, pp. 1088-1090, 1970.

[12] R. Kori, A. Saxena, and N. Upadhayay "Groundwater quality Assessment of Mandideep Industrial area," National Seminar on Environmental \& Development, Bhopal, 2006.

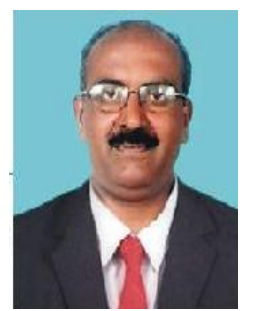

G. P. Shivashankara was born on October 7, 1958 in Mandya district, Karnataka, India. Shivashankara received a B.E in civil engineering from University of Mysore in 1983 and an M.Tech in environmental engineering from IIT Bombay in 1990 and a Ph.D for the research topic of "Chemical composition and spatial variation of bulk precipitation in Bangalore urban area" in environmental engineering from Banglore University in 1999.

Dr. G. P. Shivashankara brings with a teaching experience of 29 years and presently working as a professor in the Department of Civil Engineering of PES College of Engineering, Mandya, and Karnataka. He is a general secretary for the Mandya Zilla Science Forum. He awarded 3 Ph.D and 31 PG students under Visvesvaraya Technological University, Karnataka. He published technical papers in national and international journals of 11 and 13 respectively and few are "Precipitation chemistry at an urban area of Karnataka, India", Pollution Research (2008), "Chemical composition of bulk precipitation during 2005, Southwest Monsoon in Bangalore City, India" and "Urbanization, slums \& indoor air pollution in developing countries (2009). He visited number of countries and presented technical papers in various national and international conference. He taken 3 research papers from various agencies and completed.

$\mathrm{He}$ is a life member for Indian Society for Technical Education (ISTE) and for Indian Meteorological Society (IMS) and he is one member of Board Examiners (UG) in environmental engineering for the year 2000 in the University of Mysore also Member for Karnataka Rajya Vijyana Prasith (KRVP), Bangalore.

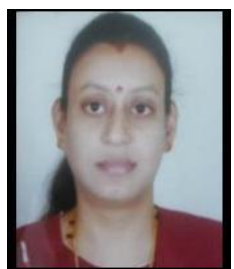

G. V. Sharmila was born on July 1, 1980 in Mandya, Karnataka, India. In 2002 she obtained her bachelor's degree in civil engineering from Visvesvaraya Technological University (VTU), Belgaum. In 2004, she obtained the masters from VTU, Belgaum in the discipline of environmental engineering and pursuing her doctoral degree.

Mrs. G. V. Sharmila worked as a lecturer in the Environmental Engineering Department of Vidyavardhaka College of Engineering and PES College of Engineering, Mandya, Karnataka, India. She has 8 years of teaching experience and guided 4 PG students. She has presented papers in national conferences and published a paper in international journal. She is a life member for ISTE.

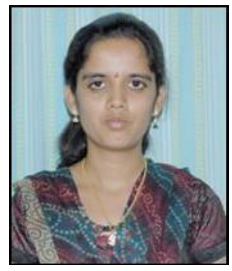

R. Shruthi was born on December 1, 1987 at Mandya, Karnataka, India. She received her bachelor degree in environmental engineering discipline from Visvesvaraya Technological University (VTU), Belgaum in 2009 and obtained the master degree from VTU, Belgaum in the discipline of Environmental Engineering in 2011 and pursuing her doctoral degree. Her research focus on rural wastewater treatment in the department of environmental engineering.

Ms. R. Shruthi has as a 4 years of teaching experience in the Department of Civil Engineering as an assistant professor at BGS Institute of Technology. She published a technical paper in international journal. 